\title{
MKI67 wt Allele
}

National Cancer Institute

\section{Source}

National Cancer Institute. MKI67 wt Allele. NCI Thesaurus. Code C49532.

Human MKI67 wild-type allele is located within 10q25-qter and is approximately $30 \mathrm{~kb}$ in length. This allele, which encodes antigen KI-67 immunoprotein, is involved in cell proliferation and cell cycle regulation. 